\title{
INDIAN PHILOSOPHY AS A JOINT PRODUCT OF DIFFERENT PHILOSOPHICAL CULTURES
}

People are of course sensitive about the achievements of their cultural regions and national identities. They can become upset to think that in singling out some areas and epochs of human history as being highly productive other countries are being downgraded. But the dignity of the human being is not related to the putative glories of her or his ancestors. Moreover, if we look at human life in a broader sweep, we see that the future is as vital as the past.

(Ninian Smart) $^{1}$

\begin{abstract}
The article shows that the concept of 'Indian Philosophy' is the joint product of two philosophical cultures. One culture is Western philosophy that feels the need for wisdom. Therefore Indian philosophy is conceived of as 'mystical' or 'spiritual' philosophy. The other is the Indian nineteenth century culture of reform thinking. Together with Western philologist the Indians highlight the 'mystical' or 'spiritual' school of Vedanta philosophy as 'the' Indian philosophy. Vedanta philosophy as spiritual philosophy distinguished India from the West. It was a political project that functioned within India's quest for independency. Modern Indian philosophers have been in the process of reconsidering this concept, especially after the appropriation of Western scientific culture.
\end{abstract}

\section{Key words}

Science, wisdom, modernity, Vedanta philosophy, theosophy, mysticism.

\section{Introduction}

In the West and the East, Indian philosophy has been known for a long time as a 'mystical philosophy'. For both Western and Indian philosophers, this qualification was not just a neutral academic description, but a polemical statement. Both wanted with this qualification to say something about their own culture, but each in a different way. Western proponents of Indian philosophy as a mystical philosophy wanted to criticize their own culture for its loss of a spiritual dimension, and especially the loss of the unity between philosophy, religion and art. Indian proponents, like Vivekanda, considered their mystical philosophy as part of a cultural identity project. "We have what the West does not have (anymore)," was their message. At the same time, this was of course also a criticism of Western culture. Indeed, for some time, European

1. Ninian Smart, World Philosophies (London: Routledge, 2001), p. 3. 
and Indian 'spiritual' thinkers could work together and feel united by this common line of critique. One could even say that the idea itself of an 'Indian' philosophy is the result of cooperation between Western thinkers and philologists, on the one hand, and modern reformist thinkers in India, on the other. The idea itself represents a culture, or, rather, two cultures. In the West, it represents an alternative, 'holistic' culture and a cultural criticism of romantic origin; in India, it represents a culture of growing anti-colonial selfconsciousness, an awareness of a national identity that distinguishes India from a West that is manifest in an overpowering science, technology and industrialization.

It is interesting to see that mystical philosophy in India, in the form of Vedanta philosophy, became, politically speaking, a very influential identity project. The first vice-president and second president of independent India was the famous scholar Sarvepalli Radhakrishan, an expert in both Indian and Western philosophy. The discussion of the 'philosophical' aspects of Indian philosophy shows that we are not only dealing with a philosophical question, but with a cultural one, too. As mentioned above, this has to do with the place of the spiritual dimension within a scientific culture. Another factor, however, is political culture. The political milieu of striving for independence and nation building determined this philosophy as well. It is very interesting to see that Vedanta philosophy, therefore, was transformed into a social-political philosophy that laid the basis for a human rights framework. This typically 'Indian philosophy' was taken out of its original context to help give foundation to a modern state. At the same time, the 'mystical' character of this philosophy was used to give India its own 'mystical' identity in opposition to the technical-materialistic West. Within this movement, two different philosophical cultures met each other. First, the cultural critical, 'alternative' philosophical culture in Europe, in which not only academic philology and philosophy were involved, but also thinkers with a personal message of wisdom, including Hermann Graf Keyserling, who interpreted Weltanschauungen like theosophy, and artistic thinkers like Henry Thoreau, Lev Tolstoy, and Romain Rolland. Running parallel is the culture of the national identity project in India. The encounter between these two cultures was effective in the construction of an Indian philosophy. Following this initial success, a new generation of Indian thinkers criticized the 'nationalistic' and 'mystical' character given to Indian philosophy as, in fact, un-philosophical. For them Indian philosophy was a individual, critical endeavor in relation to their own tradition and which has more to offer than mysticism alone. The consequences of the implementation of science, technology, industrialization and modern nation-building have determined the current agenda of Indian philosophy. The question thus arises: Can we speak of a new philosophical culture in this respect?

\section{Indian Philosophy and Philosophy as Mystical Wisdom in the West}

We can give only a short overview here of what happened to philosophy in the West that caused, at the turn of the eighteenth century, the shift towards the idea of 'Oriental philosophy', which included not only Indian, but also Chinese philosophy. Although we will only speak about Indian philosophy 
here, we will in this section use the exotic-sounding word 'Oriental philosophy', as it represents exceptionally well the atmosphere in which Indian philosophy arose. The truly philosophical character of 'Oriental philosophy' was always disputed. Among modern philosophers, Hans-Georg Gadamer, for example, did not accept the idea of 'Oriental philosophy'. This is because the borders, especially those between philosophy, religion and the sciences, are not clearly drawn in this philosophy. Philosophy, according to Gadamer, is unequivocally connected to the idea of science, and the identity of philosophy in Europe is understood in its distinction from religion and art. Gadamer presupposes the "functional differentiation between those fields as the necessary prerequisite of philosophy that started in Greece and is an essential part of European culture." ${ }^{2}$ Although Gadamer is known for his historical knowledge of Greek philosophy, this description of philosophy with regard to the other types of spiritual life is very much influenced by the movements of the nineteenth century. In that age especially, the relationship between philosophy and science became very tight and the border with religion increasingly sharply defined. This was, however, not always the case. When we look at Greek philosophy, we discover with great ease that, for Plato, philosophy was more than just science. It was the science of the good, and hence also the right way of living. It was in turn, therefore, related to happiness. Finding the path to the right way of living was, at the same time, the path towards true happiness. This search for the right way of living, based on 'the good' as the fundament of all morality, was the natural end for man as a rational being, as a being striving for the true and the good. Stoic philosophy developed, more than any other, a real philosophical lifestyle on this basis. To this lifestyle belonged meditation, 'ascetic training' and 'spiritual exercises'. To this Neo-Platonism contributed a mystical dimension. Both tendencies had such a great influence on Christianity that their practical-mystical dimension in particular disappeared into Christianity, and was integrated into its monastic lifestyle. The result, however, was that philosophy ultimately lost this dimension. In the beginning, those types of philosophies fitted very well to the Church Fathers' concept of a 'Christian philosophy', in which faith, philosophy and theology would be united. But when the borders between philosophy and theology were drawn more clearly, the ideal of a happy life being a philosophical life disappeared. This happened most of all under the influence of the introduction of Aristotelianism. Although Aristotle, at the end of his Nichomachean Ethics, talks about the philosophical life as one that focuses on the contemplation of 'divine things', such as the happy life, St Thomas Aquinas subordinated this to the happiness of faith. Therefore, in the final analysis, Aquinas can say that philosophy does not make one happy, only faith can do this. ${ }^{3}$ Philosophy was

2. Hans-Georg Gadamer, "Europa und die Oikoumene," in Hans-Georg Gadamer, Hermeneutik in Rückblick [Gesammelte Werke Bd. 10] (Tübingen: Mohr, 1995), pp. 268, 280.

3. See Pierre Hadot, Exercises spirituels et philosophie antique (Paris: Études augustiniennes 1981), and J. Aertsen, "Mittelalterliche Philosophie - ein unmögliches Projekt? Zur Wende des Philosophieverständnisses im 13. Jahrhundert," in J. A Aertsen, A. 
thus reduced to science, and to it belonged the empirical sciences that formed part of Aristotelian thought. Christianity contributed in this way to the 'secularization' of philosophy and to the introduction of the empirical sciences: philosophy is only science, nothing more. Especially with regard to non-Western philosophy, one cannot overstate the consequences for Western culture of this turn. It was the Arabs, the Muslim philosophers, who made Aristotle available for the West, but in the end the Muslim world did not accept Aristotle, while Western Christianity did. Islamic philosophy, under the influence of AlGhazali, made a turn towards mysticism instead. The positive reception of Aristotle in the West cannot be seen as an effect of Christianity as such, since Eastern Orthodox Christianity declined to accept Aristotelianism. Eastern Orthodoxy, too, preferred mysticism, e.g., in St. Gregory of Palamas, and did not make the move from Neo-Platonism to Aristotelianism. They thus closed themselves off from the development of the empirical sciences. It was the introduction of Oriental philosophy in the West, some centuries later that reintroduced mysticism into philosophy once again.

At the time of the Enlightenment, the ideal of philosophy was of course closely tied to the ideals of modern science, even though, paradoxically, Aristotelianism was the main target of its criticism. At the same time, however, the ideal of philosophy as a way of life and, therefore, as wisdom became popular again, together with the growing popularity of Stoic philosophy in general. Voltaire defended the philosophical way of life as being quiet and tolerant against the dogmatic, fanatical religious way of life, and Boethius' Consolation of Philosophy was widely read during this period. In the form of 'popular philosophy', some German philosophers in particular tried to revitalize the idea of philosophy as a wisdom everyone could attain. Kant, who was involved in the debates around this type of philosophy, defended the ideal behind it vigorously, but stressed the need for a scientific form of philosophy to begin with. Transcendental philosophy, according to him, is about the conditions of possibility of knowledge and ethics, and it is the only scientific way of actually doing philosophy: it is the necessary basis for everything that follows. ${ }^{4}$ On this account, the philosopher has a duty to inspire human beings to choose the right way of living. That approach, however, was then considered a special, 'pragmatic' branch of philosophy. Kant's own Anthropology from a Pragmatic Point of View is a book with such an aim. The wise philosophers to whom Kant turns most are Shaftesbury and Cicero. Hegel, in his turn, radicalized the ideas of Kant. He could not take seriously those 'existential' brands of philosophy that aim to help one realize one's own life. Indeed, he despised the popular Stoicism of his time and gave a place in philosophy to neither Cicero and Stoicism nor to Blaise Pascal. Therefore, 'popular philosophy' was

Speer, eds., Geistesleben im 13. Jahrhundert [Miscellanea mediaevalia, vol. 27] (Berlin \& New York: De Gruyter 2000), pp. 12-28.

4. Immanuel Kant, Verkündigung des nahen Abschlusses eines Tractats zum ewigen Frieden in der Philosophie [Akademie TextAusgabe Bd.VIII] (Berlin: Walter de Gruyter, 1968), p. 421, Kritik der Praktischen Vernunft, [Akademie TextAusgabe Bd.V] (Berlin: Walter de Gruyter, 1968), p. 63. 
no longer considered as a real philosophy and was ejected from the history of philosophy. ${ }^{5}$ In the context of the discussion titled 'What is real philosophy?' Hegel discusses the philosophical character of 'Oriental philosophy'. In this text, he outright opposes to his old, sworn enemy Friedrich von Schlegel, who occupied the first chair of indology in Germany.

Schlegel conceived of philosophy, especially Indian philosophy, from the point of view of the unity of philosophy, religion and poetry (mythology). ${ }^{6}$ It was Hegel who reproached him for taking the religion of India as its philosophy $;{ }^{7}$ here we find the roots of the discussion over whether Indian philosophy should be considered as philosophy or as religion. Schlegel wrote from the point of view of the critique of modernity. He deplored the lost unity of Europe and took refuge in other cultures, from Greek culture to Indian culture and finally the Catholic Middle Ages. The bridge linking Britain and Germany in this respect is the famous indologist Max Müller. He was familiar with the works of Kant, Schelling, Hegel and Schlegel, and as Indian and Western philologists collaborated on the publication of early Indian texts, he went to England and became the editor of the famous series The Sacred Books of the East. The exchange between Britain and Germany in fact, however, began earlier, as Hegel and Schlegel made use of the texts that were translated and edited by early British indologist like Sir William Jones, who worked in a colonial setting.

In the nineteenth century, alternative world-views like theosophy arose in the West and looked for allies in Eastern wisdom and indology. The president of the theosophist movement, Madame Blavatsky, contacted Max Müller with this goal in mind. This is a sign of the milieu in which 'Oriental wisdom' or 'Oriental philosophy' became popular: the nineteenth century was not only the world of positivism and scientific progress, but also of 'alternative' worldviews [Weltanschauungen]. 'World-views' are all-encompassing pictures of reality, in which the tendency of human thinking towards totality is accorded prime status. This drive, which, according to Kant, was a natural tendency of human thinking, could no longer be rewarded scientifically; therefore, in so far as it was a world-view, metaphysics was no science. But this drive did, nonetheless, find its goal in world-views: perspectives in which religious, philosophical and scientific ideas were united, as is now the case in the 'New Age' movement. Several political ideologies belong to this category as well, and Marxism-Leninism, as a 'scientific, all-encompassing world-view' is one of its paradoxical results.

As a reaction, the discussion about the borders between philosophy and other world-views became sharpened in academic circles. Traditional European philosophy made these frontiers still sharper and any relationship with reli-

5. G.W.F. Hegel, Vorlesungen über die Geschichte der Philosophie (Hamburg: Felix Meiner, 1994), Teil I, p. 131f.

6. F. Schlegel, Ueber die Sprache und Weisheit der Indier [orig. 1808], F. Bopp, Über das Conjugationssystem der Sanskritsprache [1816], reprint in History of Linguistics, 18th and 19th Century German Linguistics (Routledge: Thoemes Press, 1995), pp. 205 ff.

7. Hegel, Vorlesungen, Teil I, p. 376. 
gion became an object of suspicion. In this respect, it is necessary to take a close look at the famous indologist Heinrich Zimmer, who set himself off against both the German and Anglo-Saxon worlds. Deeply rooted in the Romantic tradition, he protested against both the modern scientific world-view and dogmatic Christianity, and took refuge in Indian wisdom. He understood it as philosophy, but as philosophy closely related to religion and mysticism. To defend this combination as a genuine philosophical option, he referred to Stoic and Neo-Platonic philosophy and the Christian counterparts they had in the likes of St Augustine and Meister Eckhart. ${ }^{8}$ Zimmer tells us that in his days, during the inter-war years, the idea of an Oriental or Indian philosophy was hotly debated. In fact, it was almost blasphemous to speak of 'Indian philosophy'. Gadamer, to whose circle Zimmer belonged, never accepted the idea of an Indian philosophy, as we have seen. Between the two world wars, however, when Germany in particular had to lick its wounds, there existed a philosophical climate that encouraged the acceptance of Oriental philosophy. Hermann Graf Keyserling comes to mind as an initiator of something like a 'world philosophy'. Indeed, one could foster this cultural criticism by looking back at mediaeval times, as in the case of Neo-Thomism, or at the early Romantic age of Schlegel, or try to find the solution for the problems of modern Europe by reading Nikolai Berdyaev, Lev Tolstoy and Fëdor Dostoevsky and learning about the Eastern European Orthodox world. The poems of the young Rainer Maria Rilke, the Stundenbuch [Book of Hours], are a testament to this project.

These movements, along with Theosophy and Anthroposophy, protested actively against Western rationalism. This was fertile ground for the interaction between India and Europe. When Gandhi came to England around this time, he immediately found his way in the Theosophist movement, and later, Theosophy influenced the well-known scholar on Buddhism Edward Conze. Gandhi was also influenced by Tolstoy and alternative thinkers, such as Thoreau. Rabindranath Tagore was, in these days, popular all across Europe and he found a home in the circle of the French novelist Romain Rolland, who wrote books about the Indian mystic Ramakrishna, the reformist Vivekananda, and Gandhi. In Germany, Tagore studied in Marburg and frequented the same company as Zimmer and Gadamer; he was known in the circles of Keyserling and Rilke, too. We can, therefore, speak of a specific culture in which the idea of Oriental philosophy was able to flourish. It came to fill the gap left by 'scientific philosophy' and rationalistic Christianity. It is remarkable that in those times, within Christianity and existential philosophy, Saint Augustine became popular again as representing the idea of the 'Philosophia Christiana'. This philosophical culture was jointly responsible for the reputation of Indian philosophy in Europe as a mystical philosophy, and for the reputation of India as a mystical country contrasted with the West as a technical and scientific culture. The tail end of this can be seen in the hippie and New Age movements of the 1960s.

8. Heinrich Zimmer, Philosophie und Religion Indiens (Frankfurt: Suhrkamp, 1973 [orig. Philosophies of India (Princeton, NJ: Princeton Univ. Press, 1969)]), p. 19. 
This was a holistic culture, and it referred to a wound in the history of Western philosophy. That wound was the disappearance of the ideal of philosophy as practical wisdom. Of course, this ideal did not disappear in its entirety. It could be said to have continued its existence under the guise of existential philosophy and in critical and esthetical essays. We immediately think of Søren Kierkegaard in this respect, but in the latter half of the twentieth century, for example, Michel Foucault reestablished the value of Stoic philosophy as lifestyle philosophy. Already from Romantic times onwards, the Western conception of Indian philosophy played the role of philosophy as practical wisdom, neglected by philosophical and Christian-theological rationalism. We can find here, therefore, a special 'philosophical culture', a soil in which a specific type of philosophy blooms. What made up this environment was the culture of indology, cultural criticism and alternative movements like the theosophist movement and political movements aimed at uniting the world, as well as 'world philosophy' movements. We will talk below about the decline of this philosophical culture in indological studies, together with the decline of that other 'philosophical' culture, the culture of Indian reformist thinking. Here, the idea of national identity and the tendency to describe Indian philosophy as mystical are of importance. Here too, however, the political element is also central, as it fuses with the mystical elements of Indian philosophy.

\section{Indian 'Mystical' Philosophy as an Expression of a National Identity Project}

3.A. Indian Philosophy between Colonialism and Nationalism

Western romantics are not alone in categorizing Indian thought as mystical and wise: Indian thinkers have also participated in this description. They themselves have popularized the division between scientific, technical and materialist directed thinking from Europe, on the one hand, and mystical thinking from the East, on the other. The term 'philosophy' was introduced, together with Western philosophy, to Indian thought in the nineteenth century. While philosophy as such was something new, people did recognize something in it that was already a part of their tradition. Philosophy was translated in common use as the term 'darsana'. Etymologically speaking, the meaning of 'darsana' is 'to see', and is related to the devotional view directed towards the idea of God. In relation to philosophy, however, it means a 'way of seeing' or 'system of thought' and was traditionally used in the context of the six classical Indian systems of thought: the subjects covered in it match completely the Western philosophical tradition. These systems do not deal with the mystical, monastic or semi-monastic philosophy of Vedanta alone (connected as it is with the Mimamsa School in addition to the schools of logic, epistemology and philosophy of science in the Nyava-Vaishesika), but also speaks on the dualistic Shamkya School, which is connected to the Yoga School. These six schools form the canon of Indian thought. A particular way of thinking or writing cannot be said to belong to one or the other of these six schools, as they can when it concerns the political writings, the 'arthashastras'. The arthashastras are the practically oriented writings dealing with the subject of how to handle politics, and are frequently labeled materialistic. Questions of 
political direction do not, therefore, come to the fore in the six official darsanas. This, however, was to change radically in the reformist thought of the nineteenth century with the help, as we shall see, of the mystical Vedanta philosophy.

'Darsana' does not refer to the activity of philosophizing itself; one cannot 'do darsana.' When Indian thinkers use the term 'darsana' for their own mode of thought, they do so in an objectifying and polemical context: their system of thought, 'their darsana', versus 'our darsana'. This use of the word 'darsana' clearly differs from another, competing usage, where 'darsana' is translated as 'insight into truth', a realization of the absolute. This last meaning, closest to the neutral meaning of a system of thought, came into use as a result of the interpretation from a European perspective. The term acquires a mystical meaning in the reformist thought of India, which includes the idea of a single 'Hinduism', as will be explained below. The meaning of 'to see' is interpreted as an intuitive 'Seeing,' an immediate realization of the absolute, a form of 'intellectual Anschauung [apperception]', achieved by the representatives of 'vedanta philosophy'. This 'seeing' is essentially distinct from the abstract, theoretical-objectifying spirit of European philosophy. The picture of a mystical philosophy, with religious connotations and implications for the direction of practical thought, and set off against a Western philosophy that is essentially scientific, originates in this tendency to view Vedanta thought as 'the' philosophy of India. ${ }^{9}$ But why is this mystical philosophy seen as the pre-eminent form of Indian philosophy? To answer this question, we must turn to the attempts to reform the traditional religious life of India by both the British, and thus Europeans in general, and the Indians themselves, as well as to the consequences thereof.

In a very interesting analysis, Trevor Ling shows how the English colonizers became interested in the development of an 'Indian philosophy'. ${ }^{10}$ As a reaction to the Christian inspired colonial sense of supriority of the English, especially with regard to the abuses of Indian popular religion, the higher casts in India began to develop their own 'sense of equal worth' in relation to the English by referring to their intellectual tradition. The English, troubled by local uprisings which had popular religious motivations, had political reasons for supporting this new Indian self-awareness against the arrogant Christian sense of superiotity of the missionaries. Lord Wellesley, Governor-General of India from 1797 until 1805, desired that the Indian's themselves develop a system of thought that could take hold and function as a 'civil religion' in India, an Indian Church of England. Such a civil religion, Wellesley thought, could come from the learned philosophical tradition of Brahmanism, set down in old Sanskrit texts that were preserved and studied by 'pandits' from Benares and Nabadwip. He actively promoted the study of these texts and set up a school in Calcutta in 1800, in which the study of these traditions formed part

9. Wilhelm Halbfass, Indien und Europa, Perspektiven ihrer geistigen Begegnung (Basel \& Stuttgart: Schwabe \& Co, 1981), pp. 335 ff.

10. Trevor Ling, Karl Marx and Religion in Europe and India (London: Macmillan, 1980), p. 652. 
of the training for colonial officials. Lord Hastings, Governor-General of India from 1773-1785, had previously set up a school in Bengal, also as a result of political motivations, that specialized in teaching according to Indian law books, which indologists Colebrook and Jones had derived from Schlegel and Hegel. With the help of the Brahman tradition, so Wellesley planned, work could begin on a reform of popular Indian religion from the inside out, so that the Christians and the higher casts could be content together. The British hoped that these new Indian intellectuals, coming from the higher casts, would be indebted and thus tied to them.

This political project was successful: indeed, the revival of the Sanskrit culture and the modernized variant of the Indian religion were a source of pride in their own culture among the higher casts. They felt able to claim that their culture stood on a par with that of the Europeans. In the midst of Western law and Western education, people could thus claim their own distinct identity. Vedanta thought, the mysticism of Atman and Brahman, would function superbly in this milieu. It was considered a higher, and simultaneously 'more truthful' religion of India, by which traditional popular religion could be criticized and reformed. It could also be seen as an obviously specific and distinct Indian philosophy to rival that of the West. Eventually, in this way 'Hinduism' as the religion of India came into existence. For 'Hinduism' is a neologism, consciously coined in analogy with 'Catholicism' and 'Protestantism'.

This understanding of Vedanta philosophy became part of a national identity project. The Indian texts were published with the help of English and German orientalists. The large series 'Sacred Books of the East,' edited by the German Max Müller, discussed above, who worked in England, comes to mind most as an example; the Indians themselves learned about their own religious tradition through these texts. Without these publications, in fact, the Indians would not have come into contact with their own religious heritage. It was only through these publications, which allowed the writings to pass from the hands of the religious class of priests and become accessible to everyone, that something like an 'Indian philosophy' finally became possible. On the one hand, this revolution made possible the construction of mystical philosophy, as part of a national identity project, while, on the other hand, it also led to academic relativism: it was just one philosophy among others.

\section{B. 'Mystical Philosophy' as a National Identity Project}

The great reformist thinker Ram Mohun Roy (1771-1833), who came from a rich Bengali family of the Brahman cast, had come into contact with the British orientalist movement and subsequently supported it by providing the text of the Upanishads and translations thereof in English and in the modern Indian everyday tongue. ${ }^{11}$ With this, he liberated these texts from the hands of those who had traditionally interpreted them and from their selective rules of

11. Victor van Bijlert, "Raja Rammohun Roy's Thought and its Relevance for Human Rights," in Abdullahi Ahmed An-Na'im, Jerald D. Gort, Henry Jansen, and Hendrick M. Vroom, eds., Human Rights and Religious Values: An Uneasy Relationship? (Amsterdam \& Grand Rapids: Rodopi/Eerdmans, 1995), p. 99. 
transmission. Indian thought thus 'became' philosophy with the removal of the texts from the hands of the priests.

Roy was, therefore, no longer a 'pandit', to be used by the British for a specific task, but an independent thinker in his own right. He knew English, Persian and Arabic, as well as a number of Indian languages, and later learned Hebrew, Greek and Latin in order to read the religious writings of Christianity and Judaism in their original languages; he also produced writings on Christianity. Roy took it upon himself to explain Indian tradition to the West. Within this project, he could bring Western matters into Indian thought and give them a place. According to Roy, the Upanishads and the Vedanta writings, the latter of which were based upon the former, taught a theology of enlightenment and insight, and as such represented true Hinduism. From this point onwards, he set himself the task of making the writings widely known and building upon them a program for the moral and religious renewal of Hinduism through rationality, humanity and a detailed knowledge of Hindu religious texts.

Roy developed Vedanta thought into the true (Neo-)Hinduism, which he then put to use in criticizing common idolatry and superstition. This reformation, which was welcomed by the British, was not only a superficial adjustment for the benefit of eyes in the West; it was an authentic and heartfelt evolution of Indian thought. Roy himself wanted to take this development further than the British themselves wished. He sought to gain from them a ban on the practice of burning widows, arguing that it was not in harmony with the core of Indian culture, but the British did not desire such a move. They justified their colonial obstinacy, arising from a fear of uprisings in response to such a ban, with an appeal to the cultural rights of Indians - ultimately, Roy could convince them. ${ }^{12}$ The self-consciousness that developed during the reformation as a result of reference to these rights was, against the original intentions of the British, the source of the desire of independence. On the basis of Roy's mystical view of humanity, derived from Vedanta philosophy, the Indian constitution and human rights framework were formulated.

The unique thing about Roy as a reformist figure, who took as inspiration the European reformation of Luther, is precisely that trough him the ethical values that were found in the old Indian spirituality were given a modern social and political significance. ${ }^{13}$ Originally, this philosophy was not intended for this purpose. Law and politics were dealt with through other systems entirely: in the law of Manu and the arthashastras. These contained the law of the casts and the godly right of the king. Vedanta philosophy, in contrast, did not traditionally contain questions about the exercise of power: it was meant for people who, after completing their (mainly higher) cast-prescribed family duty to work in society, wanted to connect with their 'actual self' and develop their relationship with godliness. They would withdraw from their social activities and from their families and devote themselves to religious pursuits. Roy gave this philosophy a political twist. The 'actual self', he argued, is the self of everyone and pre-supposes equal dignity.

12. Ibid., p. 100.

13. Ibid., p. 105; Halbfass, Indien und Europa, p. 236. 
Just as Roy had brought it to bear on political practice, the reformist thinker Vivekananda (1863-1902) used Vedanta thought for a national identity project. Vivekananda caused a furor at the World's Parliament of Religions in Chicago in 1893, where he emphasized the contrast between the 'mystical East' and the technological, materialistic West. With this, he gave Indians an identity and Western intellectuals critical of their own culture something that satisfied their deepest longing. Since then, Indian thought contained an inclination towards an apologetic usurpation on the understanding of 'philosophy' in the name of Vedanta. This inclination served a national and cultural selfreliance: Vedanta is philosophy and as a result, we Indians have our own philosophy which stands at the same, if not a higher, level than that of the West. ${ }^{14}$

This period of cultural discovery stimulated research into the history of Indian philosophy. For example, the great History of Indian Philosophy by Surendranath Dasgupta was published in these years. Dasgupta was even inclined to argue that specific ideas in Western philosophy already existed earlier in India. It is striking, in this context, that Indian thinkers did not use this idea of a 'mystical identity' to push Western, technical-materialistic culture out the door. This culture would in fact be held on to in its entirety. The emphasis on mysticism was, therefore, a way of holding onto a unique identity within the process of westernization. Two souls, so to speak, lived in a single chest without reconciliation.

Mystical philosophy finally proved its worth, but in a completely different area than that for which it was originally intended: politics and human rights. Vedanta philosophy came to be involved in a process of nation-building, of which Roy, Vivekananda and Gandhi were the leaders. It is, therefore, not by chance that the first vice-president and second president of India, as we noted above, was the famous Vedanta philosopher Sarvepalli Radhakrishnan. The mysticism of Vedanta was able to fill the gap in the six darsanas, within which there was a lack of resources to deal with questions of political direction.

Gandhi succeeded in transforming the ascetic practice of Indian spirituality into a means of political struggle, with which he stood up for the rights of farmers, the poor and those without cast. Just like Vivekananda, he too criticized the technical and materialistic West, and fought against modernization and for a simple lifestyle. For this reason, too, he wanted a return to the spinning wheel and the loom as means of production, perhaps also as many Indian craftsmen became unemployed as a result of the industrial production of the West. But his 'back to the spinning wheel and loom' would not be taken to heart. Jawaharlal Nehru, India's first prime minister, pressed for the development of science and technology as the key to the modernization of India. He 'translated' Gandhi's neo-Hindusm of satyagraha [the search for truth'] and ahimsa [non-violence] in terms of 'secularism', 'socialism', 'mixed economy', 'democracy', and 'neutrality'. ${ }^{15}$ With this came about a scientific and

14. Halbfass, Indien und Europa, pp. $340 \mathrm{ff}$.

15. Gerald James Larson, India's Agony over Religion (Albany: State Univ. of New York Press, 1995), p. 199; quoted from Christopher Key Chapple, "Introduction," in 
technical development, which would make India a nuclear power, and an industrialization that, together with a large increase in population, would produce an ecological disaster.

What does this say about the position of Eastern mystical philosophy? With the benefit of hindsight, we can say that we are dealing with a specific historical phenomenon and that out of this came a unique philosophical culture. The thesis of mystical philosophy as a typically Indian philosophy came to function within India's national identity project. It set Indian identity in opposition to Europe, while, as was mentioned, so much was in fact taken from Europe. At the same time, thanks to the philosophical efforts of Roy, Vivekanda and Radhakrishnan, this was not only an academic activity, but also a practical one.

This praxis, however, which they were happy to maintain as a unique property of Indian philosophy, was not a merely spiritual and ascetic practice anymore, but a political praxis of reformation. This reformation aimed at scientific education, technological development, and a legal system that had been taken from the West. This has formed the unique philosophical-cultural setting of the subsequent development of Indian philosophy. There exists in this setting a tension between, on the one hand, the borrowed technical and political culture of the West and, on the other, the emphasis in Indian philosophy on the spiritual character as typically Indian. As one might expect, the success of the reformation and the implementation of Western achievements finally removed the ground from under the promotion of spiritual philosophy as a typically Indian philosophy.

\section{C. Modern Indian Philosophy: Beyond Mysticism and Nationalism.}

In contemporary Indian philosophy, we see a tendency to take a distance from the idea that the mystical 'Vedanta philosophy' is the authentic philosophy of India. One must see the choice for the science of wisdom and its practical-soteriological focus as a very specific selection from the Indian tradition that does injustice to the scientific aspects of those traditions of thought as a whole. While the 'spiritual' Indian tradition is still usually presented as 'the' Indian philosophy, for example in school books, Indian philosophers are increasingly inclined towards a view of philosophy as science. While in earlier days a terrain was sought from which Indian philosophy could rival that of the West, now Indian philosophy confronts Western, scientific philosophy on its own turf. Radical, perhaps too radical, authors such as Daya Krishna find that the view that Indian philosophy is directed towards moshka [salvation], as we have seen in the work of Zimmer, rests on pure misunderstanding. ${ }^{16}$ Jitendra Nath Mohanty, an authority on Husserl as well as the Indian tradition, argues that while Krishna is indeed successful in unmasking this view as a myth, the construction of Western philosophy by, for example, Husserl as purely theo-

Christopher Key Chapple and Mary Evelyn Tucker, eds., Hinduism and Ecology (Cambridge MA: Harvard Univ. Press, 2000), p. xxxv.

16. Daya Krishna, Indian Philosophy, a Counter Perspective (New Delhi: Oxford Univ. Press, 1991), pp. 16-34. 
retical-scientific is similarly a myth. ${ }^{17}$ Mohanty does not deny that in Vedanta thought the concept of salvation is important, but he rejects the idea that this is something typical of Indian philosophy and that Indian philosophy deals only with this topic. It is important to see here that the self-definition of Indian philosophy signals a new phase in the confrontation with Western thought. For Mohanty, this means that the 'life-world' of the classic Vedanta is actually vanishing, as India has been determined in its course by what was borrowed from Western materialistic and scientific culture. The mystical East is thus disappearing.

The situation, however, is not completely acrimonious. There is talk of reconciliation. Such reconciliation comes from the fact that Mohanty is aware of the fact that the West is not only the 'Other' of, but also part of Indian philosophy. The two souls in this single chest have found one another. He can thus dismantle the great opposition between Eastern and Western philosophy. We must first consider, he says, the agreement and difference between distinct disciplines such as Indian grammar and Western grammar, Indian science and Western science. We must split the concept of Indian philosophy into different traditions and compare these with corresponding Western traditions. The schools of Indian thought wherein logic plays a large role, for example, are brought to the fore and can shed light on European problems, because they do not work with the traditional Western dichotomies of rationalism and empiricism, and so on and so forth.

Mohanty also argues that Indian philosophy no longer has the necessity, such as it did with Roy, to explain to modern Europeans that which is typically Indian. That is not the job of philosophy. ${ }^{18}$ That aspect of the national identity project to which Indian philosophy was bound has faded away. India has now, so writes Mohanty, seen in modernization a necessity for a political philosophy that deals with modern political demands such as democracy, capitalism and social egalitarianism. Mohanty can also, in this way, dismantle the distinction between tradition and modernity. Tradition is nothing other than living tradition, which reacts to change and, as a result, develops further. Modernity cannot, therefore, be without an element of tradition, otherwise it gets lost in an ongoing series of momentary changes. The economist and philosopher Amartya Sen wrote his book The Argumentative Indian, in which he disputes the idea that critical rationality is typically European and not Indian, with the same background in mind. For this reason, he gives pride of place to the critical argumentation in the Indian tradition and, in addition, the importance of heterodox schooling. ${ }^{19}$

We can add to this that Western indology is now 'normalized' in the sense that it no longer has the contemplative orientation of the nineteenth century;

17. Jitendra Nath Mohanty, Essays on Indian Philosophy (New Delhi: Oxford Univ. Press, 1993), pp. 44, 315.

18. J. N. Mohanty, Reason and Tradition in Indian Thought (Oxford: Clarendon Press 1992), p. 12; see also Mohanty, Essays on Indian Philosophy, p. 334

19. Amartya Sen, The Argumentative Indian (New York: Farrar, Straus and Giroux, 2005), p. xiii. 
nor does it orient itself along the lines of great philosophical systems but, rather, along those of the whole religious spectrum. This is also a necessity, as popular religion in India has developed along its own path and is no longer dominated by the pressure for reform coming from Vedanta philosophy. Contemporary Western indologists who concern themselves with Indian philosophy know that this tradition of thought is much broader than the mystical Vedanta.

Finally, the interpretation of Indian texts as Indian philosophy, analogous to Western philosophy, has had great consequences. As we have noted, the classic texts of 'Indian philosophy' functioned within the religious teacherstudent dialectic. Above all, these texts were not made accessible to everyone: they were reserved for the Brahmans. Removing the texts from the control of the priests, making them public and encouraging their academic study, as well as their philosophical interpretation (analogous to Western philosophy), has had paradoxical results. One the one hand, Indian traditional thought has become a 'philosophy', as it was opened up to each person's individual reflection and argumentation. On the other hand, however, it was through the same process that Indian thought became one academic philosophical discipline among others. You can study it if you want ..., but you are not obliged to do so. The fact that there are plenty philosophers in India who know everything about Kant and Hegel and yet nothing about Shankara and Ramanuja attests to this. Western philosophy has been for a long time already no longer specifically Western, and 'Indian philosophy' has become a specialization in both the West and the East.

At the same time, we see that increasing modernization has led to the disappearance of the specific philosophical culture that itself began the appropriation of modernity and constructed an Indian philosophy. The philosophical culture of mysticism and nationalism is, by the end of the day, to a certain extent the victim of its own success. Indian philosophy is, as we see in the thought of Mohanty, no longer a national identity project, but has become just another academic discipline among many.

\section{Conclusion: Towards a New Philosophical Culture?}

Now that Indian philosophy is just one specialization among others in philosophy, does this mean that the two philosophical approaches -that of the alternative, cultural critique and that of the national identity project- should be left by the wayside, that they no longer have any value? As far as I am concerned, the answer is "No". The content of the alternative culture-critical school, the critique of Western technological, scientific and materialistic thought, still applies; even more so as Western modernity comes to take hold everywhere. The materialistic 'diseases' of Western culture prove to be attractive to everyone. It is precisely this spread of the Western lifestyle over the whole world that reveals its material borders. One result of the ecological consequences of this is the whole culture-critical analysis of Western modernity, with its science, technology, capitalism, industrialization, domination of na- 
ture, and endless differentiation of needs. ${ }^{20}$ In politics, 'sustainability' and 'sustainable development' have now taken central stage: we would need to have three planets in order for the whole world to produce and consume at the level of Western material civilization.

My concern is, then, that the Western lifestyle is in fact not universalizable. In view of these ecological, material borders, a shortage of ideals also comes to the fore. The disappearance of an alternative like Indian philosophy means that the Western, culture-critical person can no longer take refuge in nonWestern cultures, as these are all implicated in the selfsame process. Conversely, this also means that India can no longer characterize itself as 'mystical' in opposition to the West, since the mystical philosophy of India has in no sense stood in the way of the adoption of a Western, technical-materialistic culture. Mysticism and ecological damage prove to go together very well. The national context is now no longer one of a characterization of cultural identity, but of international cooperation linked with the management of modernity, of which everyone wants to take a part, and in which everyone wants to take part.

Perhaps a new philosophical culture will come into being in this context. Of course, one cannot design such a culture. A specific philosophical culture, in fact, frequently acts as a limitation, a sort of background, that is not reflected upon, and which implies given borders. Practically speaking, however, one could well plead for the founding of a culture of philosophers who, all across the world, are in contact with one another, who are conscious of their cultural backgrounds and of the role played by the interaction between these backgrounds. The goal of such a culture would surely be the critical analysis of modernity, which is not, it should be noted, tantamount to its condemnation. Modernity is what now brings people across the world into contact with one another and this should be seen as a positive development. At the same time, however, it is on these grounds that an intercultural critique of modernity is both possible and necessary. With modernity also comes the universal critique of modernity. The object of this critique ought to be the quasi-detachment of modernity as a universal reflexivity, both in terms of theory and culture, on the one hand, and practice and materiality, on the other. ${ }^{21}$

Radboud University, Nijmegen, Netherlands

20. See Vittorio Hösle, Praktische Philosophie in der modernen Welt (München: Ch. Beck, 1995), pp. 166-99.

21. See also the interview with Thorsten Botz-Bornstein in this issue. 